\title{
HEALTH CARE REFORM AND THE CONSTITUTIONAL LIMITS ON PRIVATE ACCREDITATION AS AN ALTERNATIVE TO DIRECT GOVERNMENT REGULATION
}

\author{
Michael J. Astrue*
}

I

INTRODUCTION

My goals are modest. First, I will draw upon my personal experience during six-and-a-half years at the Department of Health and Human Services ("HHS") to make a few cultural observations about the agency in an effort to suggest why different parts of it approach private accreditation in different ways. Second, I will discuss some of the possible limitations on the use of private accreditation in the health care area, including the private delegation doctrine, a dormant area of constitutional law so treacherous that it seems to have appeal to both former Justice Brennan and Chief Justice Rehnquist as a vehicle for judicial activism.

\section{II}

\section{The Culture of Federal Health Care Regulators}

Anyone familiar with federal regulation of health care comes to realize that HHS is not an entity with a distinct institutional culture, but rather a loose collection of subagencies with strong and divergent cultures. To understand the Health Care Financing Agency ("HCFA"), it is necessary to understand that it is the offspring of the Social Security Administration and its predecessor agencies, the Social Security Board and the Federal Security Administration. ${ }^{1}$ Put simply, HCFA has viewed itself as a check-writing agency whose missions are to determine when people can receive money for doing something and then to pay that money when they do it. Historically, it has not viewed itself as a regulatory agency and has resisted legislative efforts to transform it into one. This attitude has been a constant among the senior civil servants, who stubbornly adhere to it regardless of the ideological inclinations of the political

\footnotetext{
Copyright $\odot 1995$ by Law and Contemporary Problems

* Vice President and General Counsel for Biogen, Inc.; formerly General Counsel of the United States Department of Health and Human Services, 1989 to 1992.

1. See generally CAROLYN L. WeAver, The Crisis in Social Security: Economic and POLITICAL ORIGINS 102-72 (1982).
} 
appointees who pass through the agency under the mistaken impression that they are really in charge.

Despite its strong feelings, HCFA has been slowly losing this battle. It began with incremental "back-door regulation" as Congress added what are known as the "conditions of participation" for Medicare. In other words, while Congress did not enact statutes directing HCFA to regulate the health and safety of hospitals and nursing homes, it did direct the agency not to reimburse them if they did not satisfy the increasingly broad requirements of the "conditions of participation." 2 As participation in Medicare has become an economic necessity for providers, the distinction between standard commandand-control regulation and this form of "carrot-and-stick" regulation has become largely a matter of semantics. Whether it be the patient dumping statute ${ }^{3}$ or the nursing home reform legislation, ${ }^{4}$ HCFA's predictable institutional response has been to resist additional regulatory responsibility. When it has received new authorities, usually over its objection, it has tended to assign the new task a low priority.

It is for this reason that the HHS Office of the Inspector General (the "OIG") has evolved in a way unlike the inspectors general of other agencies. In all or virtually all other federal agencies, the inspectors general operate pursuant to the Inspector General Act of $1978^{5}$ and tend to oversee a comparatively.small operation primarily focused on internal waste, fraud, and abuse.

At HHS, however, the OIG employs more than 1500 people, a number greater than the total number of employees at many substantial federal agencies. Pursuant to special authorities, ${ }^{6}$ it prosecutes Medicare and Medicaid waste, fraud, and abuse in the health care industry on behalf of the entire agency. These special delegations must be viewed in part as a congressional recognition that HCFA could not be cajoled into playing this role for itself.

This self-image as a nonregulatory agency is so strong that HCFA overcame the natural inclination of agencies to expand their jurisdiction and fiercely resisted being assigned the regulatory responsibility for the Clinical Laboratory Improvement Amendments of 1988? ? HCFA was strongly opposed to taking on the responsibility of regulating perhaps as many as 600,000 laboratories and argued internally that the Food and Drug Administration (the "FDA") would better handle this responsibility.

It is instructive to observe that the FDA would have eagerly taken on this responsibility. To understand this difference in mentality, one must understand

2. See generally 42 U.S.C. $\S 1395 \mathrm{cc}$ (1988). See also id. $\S \S 1395 \mathrm{w}-2,1395 \times(0)(6), 1395 \times(\mathrm{cc})(2)(\mathrm{I})$, $1395 \mathrm{z}, 1395 \mathrm{aa}, 1395 \mathrm{bb}, 1396 \mathrm{a}$.

3. Id. $\$ 1395 \mathrm{dd}$.

4. Id. \& $1396 \mathrm{r}$.

5. 5 U.S.C. app. $\S 11-12$.

6. See, e.g., 42 U.S.C. \& 1320a-7(b) (establishing criminal penalties for acts involving Medicare or state health care programs).

7. 42 U.S.C. $\$ 201$ note. 
that the FDA's self-image is generally one of a consumer protection agency, more akin to the Federal Trade Commission than to HCFA or the rest of HHS. Accordingly, it invariably sees expansion of its jurisdiction as increasing its protection of the public and therefore desirable. Thus, in the past few years the FDA has waged war with the Department of Agriculture to assert its jurisdiction over the regulation of seafood at the same time that it was pleading poverty as the excuse for its failure to perform some of its most important functions, such as the approval of new drugs. ${ }^{8}$ Similarly, even when Congress, in large part due to its own jurisdictional imperatives, assigned regulatory responsibility for regulation of clinical laboratories to HCFA, the FDA immediately embarked on an expansive new reinterpretation of its authority to regulate devices, submitting clinical laboratories to a confusing and unnecessary regime of dual regulation. ${ }^{9}$

Given these differences in self-image, it is unsurprising that HCFA has attempted to minimize its role as regulator through liberal use of private contractors and private accrediting agencies. Most HCFA payments made to providers are actually made by private insurance companies, and, with the exception of a small number of national coverage decisions made by HCFA, these contractors actually make most of the important coverage decisions.

HCFA has likewise been receptive to the use of private accrediting agencies. It has for some time relied upon the Joint Commission on the Accreditation of Healthcare Organizations (the "JCAHO") 10 to certify that a hospital or managed care provider has complied with HCFA's conditions of participation relating to health and safety. HCFA has also relied upon nonprofit peer review organizations to make the initial judgments with regard to most quality of care issues. Recent regulations, originally proposed in 1990, have expanded HCFA's use of private accrediting bodies and, for the first time, set up a degree of competition among accrediting agencies. ${ }^{11}$

Although the FDA occasionally incorporates commonly used scientific standards by reference, ${ }^{12}$ it is typically adamantly opposed to any delegation of its rulemaking or operational authorities, because it views such delegations as an abdication of its mission. For example, the FDA bitterly opposed certain features of the Competitiveness Council's November 1991 plan to accelerate the

8. See Prescription Drug User Fee Act of 1992, Pub. L. No. 102-571, 106 Stat. 4491 (to be codified in scattered sections of 21 U.S.C.).

9. Clinical Reference Lab., Inc. v. Sullivan, 791 F. Supp. 1499 (D. Kan. 1992).

10. The Joint Commission changed its name from the Joint Commission on Accreditation of Hospitals in 1987 to reflect the growing diversity of health care options. JOINT COMM'N ON ACCREDITATION OF HEALTHCARE ORgS., COMMITTED TO QUALITY: AN INTRODUCTION TO THE JOINT COMMISSION ON ACCREDITATION OF HEALTHCARE ORGANIZATIONS 14 (1990).

11. 58 Fed. Reg. 61,816 (1993) (to be codified at 42 C.F.R. pts. 401, 488, 489); 55 Fed. Reg. 51,434 (1990) (to be codified at 42 C.F.R. $\$ 488.9$ ).

12. Notable among these are those taken from the Pharmacopeia. See, e.g., 21 C.F.R. $\$ 73.1015$ (c) (1993) (color additives exempt from certification); id. $\$ 106.20$ (a) (infant formula quality control procedures); id. $\$ 310.500$ (b)(2)(i) (new drugs for human use); id. \& 878.5010(a) (general and plastic surgery devices). 
approval of new drug applications because the plan proposed to remove regulatory responsibility from the Agency and delegate it to university scientists. Therefore, because of the fundamentally different views of their missions, the various subagencies of HHS, exemplified by HCFA and the FDA, are likely to take opposing positions on the use of private accreditation in health care regulation.

\section{III}

\section{Constitutional Issues Relating to PRivate ACCREDItation}

To devise his health care reform plan, President Clinton convened a body of more than five hundred advisers whose identities and work he attempted to hide from public scrutiny, until he was forced to accept the proverbial "sunshine in government" by a federal district court judge. ${ }^{13}$ At least part of his rationale for this secrecy was that his advisers could not make hard decisions if all the parties interested in the process could attempt to influence the decisionmakers. Some now argue that this model should be extended to the plan itself, with groups of essentially private citizens making many critical decisions concerning health care. Certainly it appears that many of these decisions-including perhaps the definition of the basic benefits package to be offered by plans certified as qualified to participate in the new "managed competition" structure-will be made at the state or local level by a health insurance purchasing cooperative. The definition of such a cooperative is still very much up for grabs, and it is certainly possible that it will organizationally resemble traditional accrediting organizations such as the JCAHO.

Those enamored of the use of private organizations to help administer federal health programs may want to consider Justice Scalia's 1989 dissent in Mistretta v. United States, in which he declared:

I foresee all manner of "expert" bodies, insulated from the political process, to which Congress will delegate various portions of its lawmaking responsibility. How tempting to create an expert Medical Commission (mostly M.D.'s, with perhaps a few Ph.D.'s in moral philosophy) to dispose of such thorny, "no-win" political issues as the withhoiding of life-support systems in federally funded hospitals, or the use of fetal tissue for research. This is an undemocratic precedent that we set-not because of the scope of the delegated power, but because its recipient is not one of the three Branches of Government. ${ }^{14}$

Justice Scalia seems to endorse reviving an obscure constitutional doctrine that holds that the federal government may not delegate its powers to private citizens.

This effort may appear to be a lonely, even quixotic, quest for Justice Scalia. After all, the Supreme Court last employed this private delegation doctrine in

13. Association of Am. Physicians \& Surgeons, Inc. v. Clinton, 813 F. Supp. 82 (D.D.C.), rev'd, 997 F.2d 898 (D.C. Cir. 1993).

14. 488 U.S. 361,422 (1989) (Scalia, J., dissenting). 
1936 in Carter v. Carter Coal Co. ${ }^{15}$ a decision relying on one of the most abused cases of this century, A.L.A. Schechter Poultry Corp. v. United States. ${ }^{16}$ If these facts did not make the demise of the private delegation doctrine clear enough for most people, Justice Marshall declared in a 1974 opinion without objection from his peers that the doctrine "has been virtually abandoned by the Court for all practical purposes."17

Nevertheless, diverse individuals have found merit in the doctrine in diverse circumstances. Former Justice Brennan proposed revival of the doctrine in his dissent in McGautha $v$. California. ${ }^{18}$ Justice Rehnquist, in a concurring opinion, also advocated a revival of the doctrine in an Occupational Safety and Health Administration case, Industrial Union Department v. American Petroleum Institute $^{19}$ Former Chief Justice Burger joined in a similar dissenting opinion with Justice Rehnquist in American Textile Manufacturers Institute v. Donovan. $^{20}$ In another intriguing case, Larkin v. Grendel's Den, Inc., ${ }^{21}$ Professor Lawrence Tribe argued that the Court should affirm the United States Court of Appeals for the First Circuit's invalidation of a local zoning ordinance on the grounds that it constituted an unconstitutional delegation to a private party. ${ }^{22}$ In Larkin, the Supreme Court silently sidestepped the First Circuit's holding and affirmed the decision on other grounds, although the Court did hold that delegation of zoning authority to a church violated the Establishment Clause.

Litigants have attempted to strike down the use of private organizations to develop and enforce standards of care under public programs. In Cospito v. Heckler, ${ }^{23}$ patients in a psychiatric hospital challenged their hospital's loss of accreditation by the Joint Commission on Accreditation of Hospitals ("JCAH") and its decertification for federal funding by the Department of Health, Education, and Welfare ("HEW"). A divided court of appeals ignored the plain language of 42 U.S.C. section $1396 \mathrm{~d}(\mathrm{~h})(1)(\mathrm{A})$, which defined inpatient psychiatric hospital services as "inpatient services which are provided in an institution which is accredited as a psychiatric hospital by the [ $\mathrm{JCAH}^{\prime 24}$ and concluded that "no real authority was actually vested in JCAH." ${ }^{25}$ In a

15. 298 U.S. 238 (1936).

16. 295 U.S. 495 (1935).

17. Federal Power Comm'n v. New Eng. Power Co., 415 U.S. 345, 352-53 (1974) (Marshall, J., concurring). See text accompanying notes 37-71 infra.

18. 402 U.S. 183, 272 (1971) (Brennan, J., dissenting), vacated sub nom. Crampton v. Ohio, 408 U.S. 941 (1972).

19. 448 U.S. 607,687 (1980) (Rehnquist, J., concurring).

20. 452 U.S. $490,543-48$ (1981) (Rehnquist, J., dissenting).

21. 459 U.S. 116 (1982).

22. Grendel's Den, Inc. v. Goodwin, 662 F.2d 88 (1st Cir. 1981), aff'd sub nom. Larkin v. Grendel's Den, Inc., 459 U.S. 116 (1982).

23. 742 F.2d 72 (3d Cir. 1984), cert. denied, 471 U.S. 1131 (1985).

24. Pub. L. No. 92-603, \& 299B(b), 92 Stat. 1548, 1709-10, was amended on July 18, 1984 to read "inpatient services which are provided in an institution (or distinct part thereof) which is a psychiatric hospital as defined in section 1895x(f) ...." Pub. L. No. 98-369, \& 2340(b), 98 Stat. 494, 1093 (codified at 42 U.S.C. $\$ 1396 d(h)(1)(A)(1988))$.

25. Cospito, 742 F.2d at 89 n.29. 
muddled and tortuous opinion, the majority somehow found that this short and direct delegation to the JCAH included "an articulation of congressional policy sufficient to safeguard against unbridled administrative discretion." ${ }^{26}$ It also discussed at length the difficulty of requiring Congress to articulate technical standards, ${ }^{27}$ sliding over the fact that Congress has traditionally delegated such tasks to agencies, not private organizations.

In a more articulate rejection of a similar argument, a three-judge district court panel in Association of American Physicians \& Surgeons $v$. Weinberger ${ }^{28}$ rejected a series of constitutional challenges to a statute requiring the Secretary of HEW to incorporate private professional standards review organizations ("PSROs") ${ }^{29}$ into the process for denying reimbursement to providers because the services for which payment was claimed were "medically unnecessary." 30 The court held that the presence of an administrative hearing mechanism to appeal the decisions of the PSRO provided enough control over the PSRO to eliminate any constitutional concerns. ${ }^{31}$ In Corum v. Beth Israel Medical Center, ${ }^{32}$ the district court also gave short shrift to the delegation argument, holding that it was not unconstitutional for Congress to give veto power over the Secretary of HEW's rulemaking authority to a now-defunct body called "the Federal Hospital Council." 33

Although the private delegation doctrine has displayed more hardiness in health care cases in the state courts, ${ }^{34}$ it has not shown any readily apparent

26. Id. at 87 .

27. Id. at 87 n.24.

28. 395 F. Supp. 125 (N.D. Ill.), aff'd sub nom. Association of Am. Physicians \& Surgeons v. Mathews, 423 U.S. 975 (1975).

29. A PSRO

(1) is composed of a substantial number of the licensed doctors of medicine and osteopathy engaged in the practice of medicine or surgery in the area and who are representative of the practicing physicians in the area ... or has available to it the services [of such doctors] to assure that adequate peer review of the services provided by the various medical specialties and subspecialties can be assured;

(2) is able ... to perform review functions ... in a manner consistent with the efficient and effective administration of this part ... and to perform reviews of the pattern of quality of care in an area of medical practice where actual performance is measured against objective criteria which define acceptable and adequate practice; and

(3) has at least one individual who is a representative of consumers on it governing body.

Pub. L. No. 92-603, \& 249F(b), 86 Stat. 1329, 1430 (1972). Under Pub. L. No. 97-248, § 143, 96 Stat. 324, 382 (1982) (codified as amended at 42 U.S.C. $\$ 1320 c-1(1988)$ ), the PSROs are now named peer review organizations. See, e.g., 42 U.S.C. $\$ \S 1320 c-1$ to $1320 c-13$ (1988).

30. Weinberger, 395 F. Supp. at 130.

31. Id. at $140-41$.

32. 373 F. Supp. 550 (S.D.N.Y. 1974).

33. Id. at 551-53; cf. United States v. Rock Royal Coop., Inc., 307 U.S. 533, 577-78 (1939).

34. See Ware v. Benedikt, 280 S.W.2d 234 (Ark. 1955) (invalidating delegation of licensing power to county medical society); Rogers v. Medical Ass'n of Ga., 259 S.E.2d 85 (Ga. 1979) (invalidating appointment to state Board of Examiners of only those individuals recommended by the private Medical Association of Georgia); Toussaint v. State Bd. of Medical Examiners, 329 S.E.2d 433 (S.C. 1985) (holding invalid legislation mandating that governor only appoint members of private organizations to State Board of Medical Examiners); cf. Poe v. Menghini, 339 F. Supp. 986, 994-95 (D. Kan. 1972) (three-judge court) (holding that Kansas law prohibits delegation of power to promulgate binding standards to private individuals such as member of JCAH); see also Harold J. Krent, 
life in recent federal health care cases. This situation is likely to change in the coming years, however, for the following reasons: (1) health care reform will involve a massive amount of new effort, particularly at the already overloaded state level, and government agencies-out of necessity if not ideology-will be looking for as many ways as possible to delegate functions to the private sector; (2) the decisions delegated to the private sector, as predicted by Justice Scalia, will involve some of the more sensitive decisions in our lives and thus, as a matter of human nature if not as a result of consistent theories of judicial review, will receive a higher level of scrutiny than regulations that determine the maturity of an avocado based upon its oil content ${ }^{35}$ or rules that are intended to stabilize the production of bituminous coal $;^{36}$ and (3) the underpinnings of the doctrine of private delegation are mutating in ways that will give the doctrine, or a renamed successor, new vibrancy.

The private delegation cases from the twenties and thirties were based on a strong conception of separation of powers. ${ }^{37}$ For example, in A.L.A. Schechter Poultry Corp., the Court stated:

We have repeatedly recognized the necessity of adapting legislation to complex
conditions involving a host of details with which the national legislature cannot deal
directly. . . [T] The Constitution has never been regarded as denying to Congress the
necessary resources of flexibility and practicality, which will enable it to perform its
function in laying down policies and establishing standards, while leaving to selected
instrumentalities the making of subordinate rules within prescribed limits and the
determination of facts to which the policy as declared by the legislature is to apply...
[T]he constant recognition of the necessity and validity of such provisions, and the
wide range of administrative authority which has been developed by means of them,
cannot be allowed to obscure the limitations of the authority to delegate, if our
constitutional system is to be maintained. ${ }^{38}$

The Court went on to state that "Congress cannot delegate legislative power to the President to exercise an unfettered discretion to make whatever laws he thinks may be needed or advisable for the rehabilitation and expansion of trade or industry." ${ }^{39}$ The Court strengthened its position on delegation in Carter $v$. Carter Coal Co. In striking down the provisions of the Bituminous Coal

Fragmenting the Unitary Executive: Congressional Delegations of Administrative Authority Outside the Federal Government, 85 Nw. U. L. REV. 62, 110 n.176 (1990).

35. Florida Lime \& Avocado Growers, Inc. v. Paul, 373 U.S. 132 (1963).

36. Sunshine Anthracite Coal Co. v. Adkins, 310 U.S. 381 (1940).

37. See, e.g., Carter v. Carter Coal Co., 298 U.S. 238 (1936) (holding that "excise tax" affecting working conditions is not part of the congressional power to regulate commerce, but is reserved to the states); A.L.A. Schechter Poultry Corp. v. United States, 295 U.S. 495 (1935) (holding that the federal government cannot regulate the wages and hours of persons employed in the internal commerce of a state); Panama Refining Co. v. Ryan, 293 U.S. 388 (1935) (holding that $\$ 9$ (c) of the National Industrial Recovery Act was void because Congress cannot delegate legislative power to the President); Washington ex rel. Seattle Title Trust Co. v. Roberge, 278 U.S. 116 (1928) (holding that zoning measures must find their justification in the police power exerted in the public interest and unreasonable restrictions may not be imposed on private property); Eubank v. City of Richmond, 226 U.S. 137 (1912) (holding that a municipal ordinance requiring the authorities to establish building lines on separate blocks and across private property was not a valid exercise of police power).

38. Schechter, 295 U.S. at $529-30$ (citation omitted).

39. Id. at 537-38 (citation omitted). 
Conservation Act of 1935 , which delegated the power to fix maximum labor hours and minimum wages to some producers and miners, the Court categorically stated that "a statute which attempts to confer such power undertakes an intolerable and unconstitutional interference with personal liberty and private property." 40

As it became clear to the Court that this purist conception of separation of powers was standing in the way of the New Deal, this conception and the doctrines it spawned were scrapped without a great deal of ceremony or analysis. Within the space of only a few years, the Court suddenly found that delegations to private parties presented no issues worth discussing at all. ${ }^{41}$ In Currin v. Wallace, only three years after Carter Coal, the Court upheld the constitutionality of a provision of the Tobacco Inspection Act of 1935 which allowed tobacco growers to prevent the Secretary of Agriculture from inspecting their tobacco prior to sale. ${ }^{42}$ Dramatically reversing course, the Court held that there was no unconstitutional delegation of power because "Congress ha[d] merely placed a restriction upon its own regulation by withholding its operation as to a given market "unless two-thirds of the growers voting favor it." 43 The fact that it was ultimately up to the growers whether they would be subject to regulation was blithely side-stepped by the Court in distinguishing the case from anti-delegation cases such as Carter Coal. ${ }^{44}$

If revitalization of the private delegation doctrine relied on a revival of a purist conception of separation of powers, then we could probably write it off for good. After all, we live in an era in which prosecutors appointed by federal judges can prosecute executive branch officials for "conspiracy" to violate congressional appropriations riders. ${ }^{45}$ However, wholesale delegations, at least in some instances, still bother us intuitively. Imagine, for instance, a health care system that permits the local medical association to determine the criteria for providing expensive treatments to high-risk patients, a not preposterous result based on some of the current debate. Imagine also that a physician informs you that he will not be able to provide a member of your family with potentially life-saving treatment because he or she did not satisfy the local association's guidelines for treatment, which are based in part on the expense of treatment.

40. Carter Coal, 298 U.S. at 311.

41. See, e.g. Sunshine Anthracite Coal Co. v. Adkins, 310 U.S. 381 (1940) (Bituminous Coal Act of 1947 a valid delegation of power despite ability of coal producers to propose minimum prices); United States v. Rock Royal Coop., Inc., 307 U.S. 533 (1939) (Agricultural Marketing Act of 1937 not an unconstitutional delegation despite producers' referendum since "Congress had the power to put the Order into effect without the approval of anyone"); Currin v. Wallace, 306 U.S. 1 (1939) (Tobacco Inspection Act including growers referendum not an unconstitutional delegation because "Congress has merely placed a resstriction upont its own regulation"); Shields v. Utah Id. Cent. R.R., 305 U.S. 177 (1938) (Railway Labor Act not an unconstitutional delegation despite Interstate Commerce Commission's power to designate "interurban" railways).

42. 306 U.S. at 5-8.

43. Id. at 15 (citation omitted).

44. See id. at $15-16$.

45. United States v. North, 910 F.2d 843 (D.C. Cir. 1990), cert. denied, 500 U.S. 941 (1991). See generally Morrison v. Olson, 487 U.S. 654 (1988). 
Imagine further that you have heard of similarly situated but better connected persons who have received treatment despite the guidelines. Such an experience would cause many of us to begin damning the tyranny of the unelected and the self-interested.

There are signs that these types of issues will continue to bother the Supreme Court despite the occasional blanket statement about the death of the private delegation doctrine. Cynics might claim that this response would mark an ideological distaste for privatization by a judiciary certain to become much more liberal in the next few years. In fairness, however, we as a nation have become increasingly hostile to long-tolerated "conflicts of interest" to the point where the Clinton Administration has felt obliged to disqualify virtually anyone with hands-on experience in health care from its task force on health care reform, leaving a group consisting almost exclusively of civil servants, congressional staff, political appointees, and a few academics. ${ }^{46}$

This heightened sensitivity takes many forms, from increasingly onerous "ethics" laws that have nothing to do with ethics to the National Institute of Health's proposal to regulate the financial holdings of university researchers even though it lacks the statutory authority to do so. Perhaps the most instructive example of this heightened sensitivity is Melashenko v. Bowen ${ }^{47}$ one of the few decisions which the HHS OIG has ever lost. The plaintiff, Dr. Melashenko, was excluded from participating in the Medicare program by the OIG. ${ }^{48}$ Melashenko charged, inter alia, that the OIG decisionmaker, Patton, was biased, because Patton received what HHS referred to as "merit pay"; the court referred to it as a "bounty" based on the number of sanctions he imposed. ${ }^{49}$ The district court relied on the Supreme Court's ruling in Withrow v. Larkin ${ }^{50}$ in holding that the bounty system deprived Melashenko of due process because of Patton's pecuniary interest. ${ }^{51}$

The Supreme Court has, in the context of the Medicare program, treated similar types of delegation issues as due process issues. In Schweiker $v$. McClure, ${ }^{52}$ three claimants who were denied reimbursement for Part B Medicare expenses challenged the ruling of the hearing officer, who was chosen by the insurance carrier. The Court unanimously held that due process is served where (1) the hearing officers are paid out of federal, as opposed to carrier, funds, ${ }^{53}(2)$ the carriers operate under contracts that require compliance with

46. This attitude is particularly remarkable since the Federal Advisory Committee Act, 5 U.S.C. app. $\$ 1-15(1988)$, presupposes that federal agencies need the advice of those whose interests they are proposing to affect.

47. No. CV-F-87-533, 1990 WL 15990 (E.D. Cal. June 19, 1990).

48. Id. at *1.

49. Id. at $* 4$.

50. 421 U.S. 35 (1975) "[Where the decisionmaker has a pecuniary interest,] the probability of actual bias on the part of the judge or decisionmaker is too high to be constitutionally tolerable." Id. at 47 .

51. Melashenko, 1990 WL 159905 , at *4.

52. 456 U.S. 188 (1982).

53. Id. at 196-97. 
the standards set forth by statute and the Secretary of HHS, ${ }^{54}$ and (3) the hearing officer has a thorough knowledge of the Medicare program. ${ }^{55}$ What I expect to see are fewer conclusory statements that a private delegation is permissible, and a more detailed and unpredictable inquiry into the "fairness" of the delegation. As in Melashenko, courts will focus on the structure of the economic interests as they relate to standard setting and enforcement.

A second recasting of the private delegation doctrine may occur due to the partial vitality of the Appointments Clause. In the past ten years, the Court has made it clear that it is more sympathetic to separation of powers arguments when they are based on the Appointments Clause, rather than on the general scheme establishing three branches of government. In Immigration \& Naturalization Service v. Chadha, ${ }^{56}$. Congress delegated its power to suspend the deportation of aliens in certain situations to the Attorney General, but reserved the right for either house to veto any exercise of that delegated power. ${ }^{57}$ When the House of Representatives vetoed the Attorney General's suspension of deportation proceedings against Chadha, the Court stated that the legislative veto "had the purpose and effect of altering the legal rights, duties, and relations of persons, including the Attorney General, Executive Branch officials and Chadha, all outside the Legislative Branch." 58 Three years later, in Bowsher v. Synar, ${ }^{59}$ the Court held that the reporting provision of the Gramm-Rudman-Hollings $\mathrm{Act}^{60}$ was unconstitutional because it put executive power into the hands of the Comptroller General, who served at the pleasure of Congress and was; therefore, deemed to be a legislative agent. ${ }^{61}$

A similar argument HHS made with the Department of Justice provoked Congress to amend the authorization for the Medicare Geographic Classification Review Board, which had originally purported to prevent the Secretary of HHS from intervening in the decisions of lesser officers of his agency. The end result is that in this small area, despite the general eclipse of separation-of-powers jurisprudence, explicit limitations on an agency head's authority to issue rules still raise issues that concern the Supreme Court. Accordingly, cases such as Corum v. Beth Israel Medical Center ${ }^{62}$ might well be decided differently in the future.

One reason why this area is certain to be complicated is that it is impossible in practice to separate standard setting from the operational enforcement of standards. While the JCAHO may seem like a straightforward model, in most instances the rulemaking and operational roles of the private organization

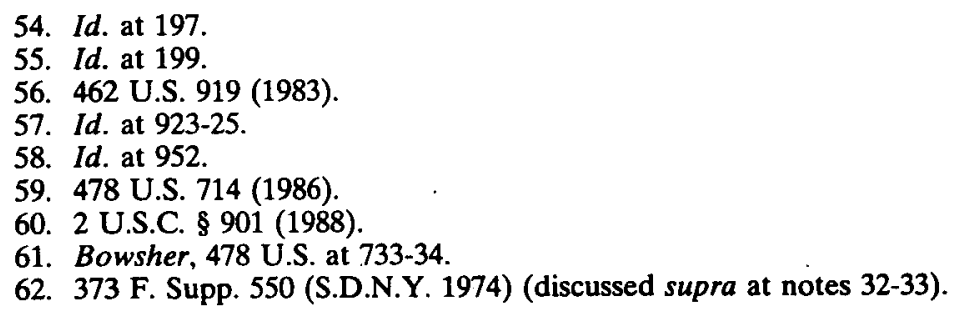


cannot be neatly severed. For instance, part of the reason the FDA was so concerned about the Competitiveness Council's private review proposal is that it would permit outsiders to develop rules at the core of the FDA's authority. Despite its critical importance to the regulation of drugs, the FDA has never articulated much in the way of regulatory interpretations of the "safe and effective" standard and relies on ad hoc standards. For instance, it has never been clear why Accutane, an acne drug with severe side effects, presented "only a labeling issue," whereas Tacrin, a drug that offered small benefits to persons with Alzheimer's but also caused side effects, did not involve "a labeling issue" and, therefore, could not be approved, at least until a recent agency change of heart.

This point can be underlined by examining the debate of and subsequent controversy over the National Organ Transplant Act of $1984,{ }^{63}$ which was amended in $1988^{64}$ and $1990 . .^{65}$ This statute conditioned the receipt of Medicare and Medicaid reimbursement upon a hospital's membership in a nonprofit organization called the United Network of Organ Sharing ("UNOS"). It also purported to require hospitals performing organ transplants to abide by the rules of this organization in order to continue to receive reimbursement. At the time of the 1988 debate over the Act, Senator Orrin Hatch (R-UT) continued a lonely, if not quixotic, battle against the Act by arguing that the statutory scheme constituted a delegation of regulatory authority to private parties and a violation of due process. ${ }^{66}$ Few observers paid much attention to Senator Hatch's arguments, and fewer were impressed by them. But recently, it has become clearer that Senator Hatch was not engaging in arcane selfindulgence.

On April 1, 1993, the Wall Street Journal reported on the subsequent development of the program. ${ }^{67}$ In 1991, a UNOS committee of twelve transplant surgeons eliminated the emergency classification in its rules, which had the effect of taking livers away from the premiere transplant centers, such as the University of Pittsburgh, and spreading them more evenly around the country. The article suggested that this change meant that more livers were being wasted, lower success rates were being tolerated, and a class of hospitals well represented by the UNOS committee was profiting. It then put a human face on this debate by detailing the long, agonizing decline of a man named Rex Voss, who died waiting for a liver under the new system.

63. 42 U.S.C. $\$ \S 273-74$.

64. Pub. L. No. 100-607, $\S \S 401-408,102$ Stat. 3048, 3114-20 (1988) (amending 42 U.S.C. $8 \S 273-274$ (Supp. V 1993)).

65. Pub. L. No. 101-616, $\S \S 201-207,104$ Stat. 3279, 3283-86 (1990) (amending 42 U.S.C. $\$ \S 273-274$

(Supp. V 1993)).

66. 134 CONG. REC. S8089 (daily ed. June 17,1988 ).

67. Scott McCartney, Agonizing Choices, WALL ST. J., Apr. 1, 1993, at A1. 
The General Accounting Office has also recently issued a report that has detailed some of the problems with UNOS. ${ }^{68}$ HHS has taken the position that UNOS lacks authority to issue rules and requirements that control Medicare reimbursement, and has declared in notice-and-comment rulemaking that UNOS rules are voluntary unless approved by the Secretary. ${ }^{69}$ Despite the uncertainty about the regulatory framework, most centers apparently have complied with most UNOS rules. ${ }^{70}$

Nonetheless, the overall result has been disturbing. Policies are inconsistent around the country, many policies may be racially discriminatory, and, in many cases, institutional access to a prestigious and lucrative area of practice has been given priority over maximization of the survival of individuals. ${ }^{71}$

\section{IV \\ CONCLUSION}

In the coming years, this nation will be making many hard choices about how to make hard choices. In Congress and in the health care industry, there is widespread disenchantment with the traditional agency model of notice-andcomment rulemaking. While it is undeniable that HCFA, the FDA, and other agencies have done much in their own ways to deserve a reputation for being sluggish and unresponsive, it is also true that Congress has responded almost every year to budgetary and political pressures by demanding an enormously complex regulatory product on short notice with a decreasing administrative budget and many staffing and procedural constraints.

If Congress looks to abandon the traditional agency model and delegate substantial new standard setting and enforcement to private organizations, it must try to sail between the proverbial Scylla and Charybdis. It can try to identify-or, as was the case with PSROs, attempt to create-organizations where the economic interests of those administering the organizations are either separate from the industry they are regulating or are sufficiently diffused so that conflict-of-interest concerns are minimal. It is, however, hard to find or manufacture such groups, and it is often fair to ask whether the group in question has the type of expertise necessary to regulate in a sensible fashion.

On the other hand, if Congress looks to find the groups that have the most expertise in the area being regulated, the legitimacy of their decisionmaking will undoubtedly be called into question, and the Supreme Court will probably reflect society's heightened concern about conflicts of interest. Even if the lonely campaigns by Justice Scalia, Senator Hatch, and others for the return of the classical private delegation doctrine do not produce a change in judicial

68. General accounting Office, Organ Transplants: InCREased Effort Needed to Boost SUPPLY AND ENSURE EQUITABLE DISTRIBUTION OF ORGANS (1993).

69. Id. at 30.

70. Id.

71. Id. at 28 ("HHS has acknowledged ... that when OPOs use transplant-center specific lists some patients with a higher priority may not be considered for an organ."). 
approaches, the same sorts of issues will almost surely return under the guise of the Due Process Clause, the Appointments Clause, or other more fashionable lines of constitutional argument. 
